\title{
Analysis of virulence factors and antibiotic resistance genes in group B streptococcus from clinical samples
}

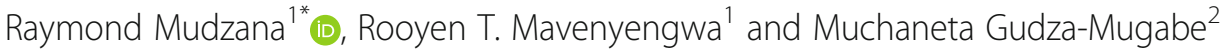

\begin{abstract}
Background: Streptococcus agalacticae (Group B Streptococcus, GBS) is one of the most important causative agents of serious infections among neonates. This study was carried out to identify antibiotic resistance and virulence genes associated with GBS isolated from pregnant women.

Methods: A total of 43 GBS isolates were obtained from 420 vaginal samples collected from HIV positive and negative women who were 13-35 weeks pregnant attending Antenatal Care at Chitungwiza and Harare Central Hospitals in Zimbabwe. Identification tests of GBS isolates was done using standard bacteriological methods and molecular identification testing. Antibiotic susceptibility testing was done using the modified Kirby-Bauer method and E-test strips. The boiling method was used to extract DNA and Polymerase Chain Reaction (PCR) was used to screen for 13 genes. Data was fed into SPSS 24.0.
\end{abstract}

Results: Nine distinct virulence gene profiles were identified and hly-scpB-bca-rib 37.2\% (16/43) was common. The virulence genes identified were namely hly 97.8\% (42/43), scpB 90.1\% (39/43), bca 86.0\% (37/43), rib 69.8\% (30/43) and bac $11.6 \%$ (5/43). High resistance to tetracycline $97.7 \%$ (42/43) was reported followed by $72.1 \%(31 / 43)$ cefazolin, 69.8\% (30/43) penicillin G, 58.1\% (25/43) ampicillin, 55.8\% (24/43) clindamycin, 46.5\% (20/43) ceftriaxone, $34.9 \%$ (15/43) chloramphenicol, and 30.2\% (13/43) for both erythromycin and vancomycin using disk diffusion. Antibiotic resistance genes among the resistant and intermediate-resistant isolates showed high frequencies for tetM 97.6\% (41/42) and low frequencies for ermB 34.5\% (10/29), ermTR 10.3\% (3/29), mefA 3.4\% (1/29), tetO 2.4\% (1/ $42)$ and linB 0\% (0/35). The atr housekeeping gene yielded 100\% (43/43) positive results, whilst the mobile genetic element IS1548 yielded 9.3\% (4/43).

Conclusion: The study showed high prevalence of $h l y, \operatorname{scp} B, b c a$ and rib virulence genes in S. agalactiae strains isolated from pregnant women. Tetracycline resistance was predominantly caused by the tetM gene, whilst macrolide resistance was predominantly due to the presence of erm methylase, with the ermB gene being more prevalent. Multi-drug resistance coupled with the recovery of resistant isolates to antimicrobial agents such as penicillins indicates the importance of GBS surveillance and susceptibility tests. It was also observed that in vitro phenotypic resistance is not always accurately predicted by resistance genotypes.

Keywords: Group B streptococcus, Virulence genes, Antibiotic resistance genes, PCR, Zimbabwe

\footnotetext{
* Correspondence: rmudzana@yahoo.com

'Department of Medical Microbiology, National Polio Laboratory, University

of Zimbabwe College of Health Sciences, P. O. Box A178, Avondale, Harare, Zimbabwe

Full list of author information is available at the end of the article
}

(C) The Author(s). 2021 Open Access This article is licensed under a Creative Commons Attribution 4.0 International License, which permits use, sharing, adaptation, distribution and reproduction in any medium or format, as long as you give appropriate credit to the original author(s) and the source, provide a link to the Creative Commons licence, and indicate if changes were made. The images or other third party material in this article are included in the article's Creative Commons licence, unless indicated otherwise in a credit line to the material. If material is not included in the article's Creative Commons licence and your intended use is not permitted by statutory regulation or exceeds the permitted use, you will need to obtain permission directly from the copyright holder. To view a copy of this licence, visit http://creativecommons.org/licenses/by/4.0/. The Creative Commons Public Domain Dedication waiver (http://creativecommons.org/publicdomain/zero/1.0/) applies to the data made available in this article, unless otherwise stated in a credit line to the data. 


\section{Background}

Streptococcus agalactiae (Group B Streptococcus; GBS) is the leading cause of neonatal infections and serious infections in pregnant women in many countries [1]. GBS generally colonizes asymptomatically as a member of the gastrointestinal or vaginal microbiota but can cause lifethreatening infections $[2,3]$. About 15 to $35 \%$ of pregnant women are colonized vaginally, and approximately 1 to $2 \%$ of colonized neonates develop a severe infection [4]. About $25 \%$ of pregnant women have S. agalactiae in their rectum or vagina [1] which can be passed via vertical transmission to the unborn baby leading to early onset disease in the form of sepsis, pneumonia and meningitis [4].

In low income countries such as Zimbabwe, pregnant women hardly get access to GBS diagnostic tests and antibiotics are not generally affordable for the general public. A study done in three communities in Zimbabwe showed a cumulative $60.3 \%$ GBS colonization rate of women who were tested 3 times and that same study showed that GBS colonization is common among pregnant women in the country [5].

S. agalactiae uses virulence factors (VFs) encoded by its genes to enter, replicate and persist in a host [6]. Antimicrobial resistance genes confer GBS the ability to resist the effects of medication and these genes are found in the environment [7]. The increasing emergence of antibiotic resistant $S$. agalactiae clearly raises concern for sustained measures in treatment of such lifethreatening bacterial infection [8].

The virulence factors in GBS include the capsular polysaccharide antigens (CPA) which is used for strain typing $[9,10]$. In Zimbabwe, CPA serotyping and nucleic acid based methods have been used to characterize GBS antigens $[11,12]$. Other genes that have been studied in other countries include those for the alpha/ $\alpha$ antigens of the $C$ protein $(b c a)$, beta/ $\beta$ antigens of the $C$ protein $(b a c)$, surface protein Rib (rib), C5a peptidase $(s c p B)$ and hyaluronate lyase $(h l y)[6,9,13]$. To our knowledge only one study [11] in this country investigated Rib, $\mathrm{C} \alpha$ and $\mathrm{C} \beta$ protein markers in GBS. However, data on some of the other known virulence genes is not yet available.

Penicillin and ampicillin are the drugs of choice for treatment of human $S$. agalactiae infections [14-16] whereas for penicillin-allergic individuals, erythromycin and clindamycin are recommended [1]. Generally, GBS is regarded to be $100 \%$ susceptible to penicillin and ampillicin [14, 17, 18]. However, some studies in Ethiopia, USA and Japan have reported clinical isolates exhibiting intermediate and reduced susceptibility to both penicillin G and ampicillin [19-23]. The prevalence of resistance to erythromycin, tetracycline and clindamycin has recently been increasing in $S$. agalactiae $[14,15$, 24]. Various researchers have linked this resistance to specific genes found in GBS $[14,16,25]$.
Molecular tests are necessary when monitoring the spread of resistant organisms and their genes throughout the communities and medical facilities such as hospitals and clinics [26]. Such tests are important if we are to control the increase in resistance as well as the emergence of multi-drug resistant bacteria. A good example being the study of mobile genetic elements (MGEs) which are a type of DNA that can move around and within the genome [27]. Strategies to fight off bacterial infections by targeting specific virulence genes and mobile genetic elements have been suggested [28].

A total of 13 genes were screened in GBS including 5 virulence genes hyaluronate lyase, $h l y$; beta/ $\beta$ antigens of the $C$ protein $(b a c)$; alpha/ $\alpha$ antigens of the $C$ protein $(b c a)$; surface protein Rib, rib [9] and C5a peptidase, $s c p B$ [29]. The 6 antibiotic resistance genes investigated are the tetracycline resistance determinants tet $M$ and tetO [25]; erythromycin ribosomal methylase determinants ermB and ermTR; Macrolide efflux mefA and clindamycin resistance determinant $\operatorname{lin} B$ [14]. The Mobile Genetic Element IS1548 [9] and the housekeeping gene atr [30] was also amplified. The atr gene was selected for analysis in the current study because it is an excellent target for S. agalactiae identification. It is an essential gene which has been well studied and has a low probability of mutation [30].

GBS virulence and antibiotic resistance gene studies are important in the development of vaccines and in understanding the resistance mechanisms used by pathogens, respectively. The aim of this study was to identify virulence factors and antibiotic resistance genes found in GBS isolates from pregnant women clinical samples as well as to study the phenotypic antimicrobial resistance and the correlation between the different genes found in GBS isolates.

\section{Methods \\ Study design and sample collection}

A cross-sectional study was carried out enrolling 420 healthy pregnant women of 35-38 gestational age on their scheduled Antenatal Care (ANC) routine visit at the Harare and Chitungwiza Central hospitals in Zimbabwe. Using a consecutive sampling method two vaginal swabs were collected during October 2016 to November 2016 period from which the 43 GBS isolates were obtained. Consenting participants were administered with a questionnaire to obtain demographic data, syphilis and HIV status. This was performed by trained research nurses.

\section{Inclusion and exclusion criteria}

Participants who were on treatment for any STI and those who had received antibiotic treatment 1 month prior to recruitment were excluded from the study. All pregnant women who did not give their consent as well 
as those who were less than 13 weeks pregnant and less than 18 years of age were also excluded from the study.

\section{Sample size determination}

Sample size was calculated using a single proportion estimate with specified precision. A two sided significance level alpha was set at $5 \%$, power of $80 \%$ and a prevalence of GBS in Zimbabwe of $31.6 \%$ according to Moyo et al., (2000) [31]. The sample size was based on an estimated proportion of 0.33 , confidence level of 0.95 and a desired precision of estimate of 0.005 . The estimated sample size became 340 plus $5 \%$ attrition giving a total minimum sample size of $\underline{357}$.

\section{Isolation and identification of Streptococcus agalactiae}

A total of 43 suspected GBS isolates were obtained from the vaginal swabs. These isolates were subcultured by streaking onto $5 \%$ sheep blood agar plate (Columbia CNA Agar) (Acumedia, USA). The plates were incubated at $37^{\circ} \mathrm{C}$ for $18-24 \mathrm{~h}$ in aerobic conditions. The suspected $\beta$-hemolytic colonies were identified as GBS using standard microbiological $S$. agalactiae identification tests such as the Gram stain (gram positive cocci), the Catalase test (catalase negative), Bile Aesculin test, CAMP (Christie, Atkins, Munch, Petersen) test which were confirmed using the Streptex grouping latex reagent (Remel, UK). The isolates identified as GBS strains were then stored in a cation-adjusted Mueller Hinton broth along with $20 \%$ glycerol at $-80^{\circ} \mathrm{C}$. The negative culture results were issued after $72 \mathrm{~h}$.

\section{Antimicrobial susceptibility testing}

The following 9 antimicrobial discs (Oxoid, Basingstoke, UK) and concentrations were selected: penicillin G (10 units), ampicillin $(10 \mu \mathrm{g})$, vancomycin $(30 \mu \mathrm{g})$, cefazolin $(30 \mu \mathrm{g})$, ceftriaxone $(30 \mu \mathrm{g})$, chloramphenicol $(30 \mu \mathrm{g})$, tetracyline $(30 \mu \mathrm{g})$, clindamycin $(2 \mu \mathrm{g})$ and erythromycin $(15 \mu \mathrm{g})$. Antimicrobial susceptibility testing (AST) of GBS was done on 5\% sheep blood containing MuellerHinton agar using the modified Kirby Bauer methods as recommended by the Clinical Laboratory Standard Institute (CLSI 2017) [32]. The medium was poured into 90 $\mathrm{mm}$ diameter sterile petri dishes to a depth of $4 \mathrm{~mm}$ (about $25 \mathrm{ml}$ per plate). This was done on a level surface so that the depth of the medium is uniform. Bacterial inocula were prepared by suspending 3-4 freshly grown GBS colonies in $3-5 \mathrm{ml}$ sterile physiological saline and turbidity was adjusted to 0.5 McFarland standard used as a reference to adjust the bacterial suspension. A sterile cotton swab was used to inoculate and excess fluid was removed by pressing and rotating the swab against the side of the tube above the level of the suspension. It was then swabbed over the entire surface of the agar. Then, water-soluble antibiotic impregnated paper disks were placed on the plate and incubated in $5 \% \mathrm{CO}_{2}$ at $37^{\circ} \mathrm{C}$ for $24 \mathrm{~h}$. Incubated, plates were examined to ensure the growth was confluent or near confluent before zone diameters were measured. The minimum inhibitory concentrations (MICs) of ampicillin, chloramphenicol and vancomycin were also confirmed using E-test strips (BioMerieux, Basingstoke, UK). The MICs for three antimicrobials were defined as the lowest concentration of antibiotic that completely inhibited bacterial growth. The susceptibilities of GBS to antibiotics were categorized as sensitive, intermediate and resistant based on the CLSI 2017 guidelines [32].

\section{Quality control}

Streptococcus pneumoniae (ATCC 49619), Streptococcus agalactiae (ATCC 12386), Escherichia coli (ATCC 25922) and Staphylococcus aureus (ATCC 29213) were used as quality control in this study.

\section{DNA isolation and quantification}

After subculturing the stored isolates, DNA was extracted using thermal lysis (the boiling method). A pipette was used to place $600 \mu \mathrm{l}$ of sterile Tris-EDTA (TE) buffer pH 8.0 (Amresco, USA) into a $1.5 \mathrm{ml}$ sterile Eppendorf tube. A sterilized loop was used to emulsify the cultured colonies in TE and this mixture was vortexed for 30-45 s before placing the tightly closed Eppendorf tubes into a boiling water bath for $15 \mathrm{~min}$. A $-20^{\circ} \mathrm{C}$ freezer was then used to freeze the boiled mixture for $10 \mathrm{~min}$. DNA samples were stored at $-20^{\circ} \mathrm{C}$ in Tris-EDTA buffer at pH 8.0 to minimize the degradation, before being tested for quality and quantity. The preparation of $\times 1$ Tris-Borate electrophoresis (TBE) buffer, $1 \%$ agarose gel and molecular weight markers (1 $\mathrm{kb}$ and $50 \mathrm{bp}$ ) were all done according to manufacturer's instructions.

The PCR process was done in four stages, i.e. amplification of the housekeeping gene atr, the mobile genetic element IS1548, the antibiotic resistance genes (ermB, ermTR, mefA, $\operatorname{lin} B$, tet $M$ and tetO) and the virulence genes ( $h l y, b c a, b a c, r i b$ and $s c p B)$.

\section{PCR reactions mixtures and conditions}

Amplification of all the genes was done using standard PCR. For each DNA sample a $25 \mu \mathrm{l}$ reaction mixture was made which consisted of $15.875 \mu \mathrm{l}$ of nuclease-free water (Amresco, USA), $2.5 \mu \mathrm{l}$ of $\times 10$ PCR buffer (New England BioLabs, UK), $0.5 \mu \mathrm{l}$ of dNTPs Solution Mix, $10 \mathrm{mM}$ (New England BioLabs, UK), $0.125 \mu \mathrm{l}$ Taq DNA polymerase, $5 \mathrm{U} / \mu \mathrm{l}$ (New England BioLabs, UK), $5 \mu \mathrm{l}$ of DNA template and $1 \mu \mathrm{l}$ of the $10 \mu \mathrm{M}$ primer $(0.5 \mu \mathrm{l}$ of forward primer and $0.5 \mu \mathrm{l}$ of reverse primer) (Inqaba biotech, South Africa). The primers used in our study are listed (see Additional file 2: Table S1). It should be 
noted that for each PCR test, DNA samples of clinical isolates were simultaneously proliferated and evaluated with a positive control sample (DNA sample of $S$. agalactiae, ATCC 12386) and a negative control (Nuclease free water). A Labnet Multigene OptiMax (Labnet International Inc., USA) was used for the PCR thermal cycling conditions with an initial denaturation step at $94{ }^{\circ} \mathrm{C}$ for $1 \mathrm{~min}, 35$ cycles \{denaturation $94^{\circ} \mathrm{C}$ for $1 \mathrm{~min}$, annealing at $55^{\circ} \mathrm{C}$ for $1 \mathrm{~min}$, extension $72^{\circ} \mathrm{C}$ for $\left.1 \mathrm{~min}\right\}$ and a final elongation step at $72{ }^{\circ} \mathrm{C}$ for $10 \mathrm{~min}$. Ten microliters of the amplified products were mixed with $5 \mu \mathrm{l}$ of gel loading dye $(6 \times)$ then run along a $1 \%$ ethidium bromide (Amresco, USA) (EtBr final conc. of $0.5 \mu \mathrm{l} / \mathrm{ml}$ ) stained agarose gel with a $1 \mathrm{~kb}$ and $50 \mathrm{bp}$ DNA ladder (New England BioLabs, UK) in 1× TBE buffer (Amresco, USA) for $1 \mathrm{~h} 30 \mathrm{mins}$ at $100 \mathrm{~V}$ (Biobase, China) and then viewed using a Wealtec KETA UV Transilluminator (Wealtec Corp, USA).

The contents of each $25 \mu$ reaction mixture is summarized in Table 1. Optimization of the PCRs was performed by adjusting the DNA template concentration and the annealing time.

\section{Statistical analysis}

All data entry and analysis was done using IBM Statistical Package for the Social Sciences (SPSS) version 24.0 software. Prevalence figures were calculated for the total sample population. Tests for normality were done such as the Shapiro-Wilks test and Skewness-Kurtosis All Normality Test. $P$ value less than 0.05 was considered statistically significant.

\section{Sample characteristics}

\section{Tetracyline resistance genes}

A Shapiro-Wilks test $(p<0.05)$ and a visual inspection of their histograms, normal Q-Q plots and box plots showed that tetracycline resistance was not normally distributed for tet $M$ and tet $O$ with a skewness of 6.481

Table 1 Final primer concentrations and volumes used in the PCRs

\begin{tabular}{lll}
\hline Components & $\begin{array}{l}\mathbf{2 5} \boldsymbol{\mu l} \\
\text { Reaction }\end{array}$ & Final Conc. \\
\hline $\begin{array}{l}\text { 10× PCR Standard Taq } \\
\text { reaction buffer }\end{array}$ & $2.5 \mu \mathrm{l}$ & $1 \times$ \\
$10 \mathrm{mM}$ dNTPs Solution Mix & $0.5 \mu \mathrm{l}$ & $200 \mu \mathrm{M}$ \\
$10 \mu \mathrm{M}$ Forward Primer & $0.5 \mu \mathrm{l}$ & $0.2 \mu \mathrm{M}$ \\
$10 \mu \mathrm{M}$ Reverse Primer & $0.5 \mu \mathrm{l}$ & $0.2 \mu \mathrm{M}$ \\
Template GBS DNA & $5 \mu \mathrm{l}$ & variable \\
Taq DNA Polymerase & $0.125 \mu \mathrm{l}$ & $1.25 \mathrm{U} / 50 \mu \mathrm{ICR}$ \\
Nuclease Free Water & $15.875 \mu \mathrm{l}$ & - \\
\hline
\end{tabular}

$(\mathrm{S} . \mathrm{E}=0.365)$ and a kurtosis of $42(\mathrm{~S} . \mathrm{E}=6.717)$ for both tet $M$ and tet $O$.

\section{Erythromycin resistance genes}

A Shapiro-Wilks test $(\mathrm{p}<0.05)$ and a visual inspection of their histograms, normal Q-Q plots and box plots showed that erythromycin resistance was not normally distributed for ermTR, mefA and $\operatorname{ermB}$, with a skewness of $2(\mathrm{~S} . \mathrm{E}=1.014)$ and a kurtosis of $4 \quad(\mathrm{~S} . \mathrm{E}=$ 2.679) for ermTR, a skewness of $0.816(\mathrm{~S} . \mathrm{E}=0.369)$ and a kurtosis of $-1.405(\mathrm{~S} . \mathrm{E}=0.724)$ for $m e f A$ and a skewness of $0.321(\mathrm{~S} . \mathrm{E}=0.409)$ and a kurtosis of $2.023(\mathrm{~S} . \mathrm{E}=0.793)$ for $\mathrm{ermB}$.

Clindamycin resistance and the $\operatorname{lin} B$ gene could not be tested for normality because linB's absence was constant and that showed a complete absence of correlation which is represented by 0 . The VFs could not also be tested for normality, because they did not have an established dependent and independent variable, however a correlation did exist. Since the data that was tested is not normal, we used non-parametric test, such as the Spearman rank correlation test (see Additional file 2: Table S5). A $p$-value of 0.05 was used for determining statistical significance.

\section{Results}

\section{Participant characteristics}

A total of 420 Zimbabwean pregnant women between 13 and 35 weeks of gestation with a median age of 29 years were recruited and sampled in the study. Of these $10.2 \%(43 / 420)$ were vaginally colonized by GBS and of the 43 women, $95.3 \%$ (41/43) were HIV-uninfected and $4.7 \%(2 / 43)$ were HIV-infected.

\section{Antibiotic susceptibility profiles}

The 43 GBS isolates in Table 2 suggest a 97.6\% (42/43) resistance of GBS to tetracycline, $72.1 \%(31 / 43)$ cefazolin, 69.8\% (30/43) penicillin G, 58.1\% (25/43) ampicillin, $55.8 \%(24 / 43)$ clindamycin, 46.5\% (20/43) ceftriaxone, $34.9 \%$ (15/43) chloramphenicol, and 30.2\% (13/43) for both erythromycin and vancomycin.

\section{Multi-drug resistance pattern}

Multidrug resistance (MDR) ( $\geq 3$ drug classes) was detected in $67.4 \%(29 / 43)$ of the isolates. Resistance to 5,6 , 7,8 and 9 drugs was found to be $34.2 \%, 17.0 \%, 23.9 \%$, $20.6 \%$ and $3.4 \%$ respectively as shown in Table 3 .

\section{Virulence gene profiles}

Nine distinct virulence gene profiles were identified and the virulence gene profiles hly-scpB-bca-rib 37.2\% (16/ $43)$ and $h l y$-scpB-bca $18.6 \%$ (8/43) were common among GBS isolates as shown in Table 4. 
Table 2 Antibiotic susceptibility profiles of 43 GBS isolates from pregnant women

\begin{tabular}{|c|c|c|c|c|c|c|}
\hline \multirow[t]{2}{*}{ Antibiotic } & \multirow[b]{2}{*}{ Resistant no. (\%) } & \multirow[b]{2}{*}{ Intermediate no. (\%) } & \multirow[b]{2}{*}{ Susceptible no. (\%) } & \multicolumn{3}{|c|}{$\operatorname{MIC}(\mu \mathrm{g} / \mathrm{ml})^{c}$} \\
\hline & & & & $\mathrm{MIC}_{50}$ & $\mathrm{MIC}_{90}$ & Range \\
\hline \multicolumn{7}{|l|}{ Disk diffusion ${ }^{a}$} \\
\hline Penicillin G (10 units) & $30 / 43(69.8 \%)$ & $0(0 \%)$ & $13 / 43(30.2 \%)$ & d- & - & - \\
\hline Ampicillin $(10 \mu \mathrm{g})$ & 25/43 (58.1\%) & $0(0 \%)$ & 18/43 (41.9\%) & - & - & - \\
\hline Tetracycline $(30 \mu \mathrm{g})$ & $42 / 43(97.6 \%)$ & $0(0 \%)$ & $1(2.3 \%)$ & - & - & - \\
\hline Clindamycin $(2 \mu g)$ & 24/43 (55.8\%) & $11 / 43(25.6 \%)$ & 8/43 (18.6\%) & - & - & - \\
\hline Erythromycin $(15 \mu \mathrm{g})$ & 13/43 (30.2\%) & 16/43 (37.2\%) & 14/43 (32.6\%) & - & - & - \\
\hline Vancomycin $(30 \mu \mathrm{g})$ & $13 / 43(30.2 \%)$ & $0(0 \%)$ & 30/43 (69.8\%) & - & - & - \\
\hline Cefazolin $(30 \mu \mathrm{g})$ & $31 / 43(72.1 \%)$ & $0(0 \%)$ & $12 / 43(27.9 \%)$ & - & - & - \\
\hline Chloramphenicol $(30 \mu \mathrm{g})$ & 15/43 (34.9\%) & $16 / 43(37.2 \%)$ & $12 / 43(27.9 \%)$ & - & - & - \\
\hline Ceftriaxone $(30 \mu \mathrm{g})$ & 20/43 (46.5\%) & $0(0 \%)$ & 23/43 (53.5\%) & - & - & - \\
\hline \multicolumn{7}{|l|}{ E-test ${ }^{b}$} \\
\hline Ampicillin & 20/43 (46.5\%) & $0(0 \%)$ & 23/43 (53.5\%) & 0.25 & 0.75 & 0.016 to 4 \\
\hline Vancomycin & $16 / 43(37.2 \%)$ & $0(0 \%)$ & $30 / 43(63.7 \%)$ & 1 & 4 & 0.25 to 8 \\
\hline Chloramphenicol & 0/43 (0\%) & 2/43 (4.7\%) & 12/43 (95.3\%) & 1.5 & 4 & 0 to 12 \\
\hline
\end{tabular}

${ }^{a}$ Testing was performed by disk diffusion

b Testing was performed with E-test

${ }^{\mathrm{C}} \mathrm{MIC}_{50}$ and $\mathrm{MIC}_{90}$, MICs at which 50 and $90 \%$ of isolates were inhibited, respectively

d - , not available

Table 3 Multi-drug resistance pattern of GBS isolated from pregnant women recruited from two health institutions ( $n=43$ )

\begin{tabular}{|c|c|c|c|}
\hline Pattern & Drugs resistance pattern (Antibiogram) & No. of drug to which strains were resistant & No. of MDR strains (\%) \\
\hline I & AMP:PEN:CEFA:VAN:TET & 5 & $3 / 29(10.3 \%)$ \\
\hline$\|$ & AMP:PEN:CEFA:CLN:TET & 5 & $2 / 29(6.9 \%)$ \\
\hline III & AMP:PEN:CEFA:CHL:TET & 5 & $1 / 29(3.4 \%)$ \\
\hline IV & AMP:PEN:CLN:CRO:TET & 5 & $1 / 29(3.4 \%)$ \\
\hline V & AMP:CEFA:CLN:CRO:TET & 5 & $1 / 29(3.4 \%)$ \\
\hline $\mathrm{Vl}$ & PEN:CEFA:CLN:CRO:TET & 5 & $1 / 29(3.4 \%)$ \\
\hline VII & CEFA:ERY:CLN:CHL:TET & 5 & $1 / 29(3.4 \%)$ \\
\hline VIII & AMP:PEN:CEFA:ERY:CRO:TET & 6 & $1 / 29(3.4 \%)$ \\
\hline IX & AMP:PEN:CEFA:CLN:CRO:TET & 6 & $1 / 29(3.4 \%)$ \\
\hline$x$ & PEN:CEFA:CLN:CHL:CRO:TET & 6 & $1 / 29(3.4 \%)$ \\
\hline$X I$ & PEN:ERY:CLN:CHL:CRO:TET & 6 & $1 / 29(3.4 \%)$ \\
\hline XII & CEFA:ERY:CLN:CHL:CRO:TET & 6 & $1 / 29(3.4 \%)$ \\
\hline XIII & AMP:PEN:CEFA:VAN:ERY:CLN:TET & 7 & $3 / 29(10.3 \%)$ \\
\hline XIV & AMP:PEN:CEFA:VAN:CLN:CRO:TET & 7 & $1 / 29(3.4 \%)$ \\
\hline$x V$ & AMP:PEN:CEFA:ERY:CLN:CRO:TET & 7 & $1 / 29(3.4 \%)$ \\
\hline$X \mathrm{VI}$ & AMP:PEN:CEFA:VAN:CHL:CRO:TET & 7 & $1 / 29(3.4 \%)$ \\
\hline$X V I I$ & AMP:PEN:CEFA:CLN:CHL:CRO:TET & 7 & $1 / 29(3.4 \%)$ \\
\hline XVIII & AMP:PEN:CEFA:VAN:CLN:CHL:CRO:TET & 8 & $3 / 29(10.3 \%)$ \\
\hline XXIV & AMP:PEN:CEFA:ERY:CLN:CHL:CRO:TET & 8 & $2 / 29(6.9 \%)$ \\
\hline$x X X$ & AMP:PEN:CEFA:VAN:ERY:CLN:CHL:TET & 8 & $1 / 29(3.4 \%)$ \\
\hline$X X X \mid$ & AMP:PEN:CEFA:VAN:ERY:CLN:CHL:CRO:TET & 9 & $1 / 29(3.4 \%)$ \\
\hline
\end{tabular}

AMP Ampicillin, PEN Penicillin G, CEFA Cefazolin, VAN Vancomycin, ERY, Erythromycin, CLN Clindamycin, CHL Chloramphenicol, CRO Ceftriaxone, TET Tetracycline (based on disk diffusion method) 
Table 4 Virulence gene profiles of the 43 Streptococcus agalactiae isolates

\begin{tabular}{lll}
\hline Virulence Gene Profile & Number of Isolates & Frequency \% \\
\hline hly, bca & 1 & 2.3 \\
hly, bca, rib & 3 & 7.0 \\
hly, scpB, rib & 6 & 14.0 \\
hly, scpB, bca & 8 & 18.6 \\
hly, scpB, bca, rib & 16 & 37.2 \\
hly, scpB, bca, rib, bac & 1 & 2.3 \\
$h l y$, scpB, bca, bac & 4 & 9.3 \\
scpB, bca, rib, IS1548 & 1 & 2.3 \\
hly, scpB, bca, rib, IS1548 & 3 & 7.0 \\
\hline
\end{tabular}

\section{Prevalence of virulence genes and antibiotic resistance genes}

Table 5 shows the percentages of all the genes being investigated (see Additional file 2: Table S2). The housekeeping gene atr was present in all 43 isolates, whilst the MGE IS1548 was present in only 4 of the isolates. The virulence gene hly had the highest frequency followed by $s c p B, b c a$, rib but bac which was found in a few isolates. The VFs frequencies were calculated for the whole GBS population (43 isolates). The antibiotic resistance gene tet $M$ had a high percentage when compared with tet $O$. The $\operatorname{erm} B$ determinant was moderately present followed by $\operatorname{ermTR}$ and $m e f A$ which was rarely found. The $\operatorname{lin} B$ gene was not detected in any of the isolates. The percentage of the resistant determinants was obtained by

Table 5 Frequency of all the 13 genes in the 43 GBS isolates

\begin{tabular}{lll}
\hline Name of Gene & Primer Name & Frequency (\%) \\
\hline Housekeeping Gene & atr & 100 \\
Mobile Genetic Element & & \\
& IS1548 & 9.3 \\
Virulence Genes & & \\
Hyaluronate lyase & hly & 97.8 \\
C5a peptidase & scpB & 90.1 \\
alpha/a antigens of the C protein & bca & 86.0 \\
Surface protein Rib & rib & 69.8 \\
beta/ $\beta$ antigens of the C protein & bac & 11.6 \\
Antibiotic Resistance Genes & & \\
Tetracycline Resistance & tetM & 97.6 \\
Tetracycline Resistance & tetO & 2.4 \\
Erythromycin Ribosomal Methylase & ermB & 34.5 \\
Erythromycin Ribosomal Methylase & ermTR & 10.3 \\
Macrolide efflux & mefA & 3.4 \\
Clindamycin Resistance & linB & 0 \\
\hline
\end{tabular}

combining only the intermediate and resistant populations $(\mathrm{I}+\mathrm{R})$ (see Additional file 2: Table S3).

\section{Discussion}

Our study is the first prevalence report of detection of some of the GBS virulence genes and antibiotic resistance genes in pregnant women in Zimbabwe. The 10.2\% prevalence of maternal GBS colonization reported is similar to the $12.2 \%$ and $13.4 \%$ reported in Ethiopia [19] and Saudi Arabia [33], respectively. However, its lower when compared to the 2010 study in Zimbabwe [5] and this could be due to the effectiveness of some of the ongoing awareness campaigns on pregnant women's health and early testing. Other possible reasons for these discrepancies are differences in the time of sampling, specimen, sample sizes, geography, detection techniques and gestational ages among other factors.

\section{The atr gene and the Mobile genetic element}

The sensitivity of the atr gene amplification, in this study was $100 \%$ (43/43) (Table 5) which is similar to what is reported in other studies done by Gavino and Wang [34], de-Paris et al., [30] and Alfa et al. [35], where sensitivity was $95.8 \%, 100 \%$ and $90.5 \%$ respectively. This high sensitivity may be attributed to the use of selective and enriched media prior to performing PCR. Since this PCR test has shown to be reliable and robust, future studies can focus on rapidly testing pregnant women who present in labor with unknown GBS status. This test was used as a GBS confirmatory identification test. The Mobile Genetic Element IS1548 was present in only $9.3 \%(4 / 43)$ (Table 5). This finding is contrary to an Iranian study which showed that the gene is more prevalent in human than in bovine (77\% vs 5\%) GBS isolates [9]. The origin of the isolates could be a possible explanation for such a difference.

\section{Virulence genes}

Nine distinct virulence gene profiles were observed but $30 / 43$ strains (69.8\%) belonged to hly-scpB-bca-rib $37.2 \%$ (16/43), hly-scpB-bca $18.6 \%$ (8/43) or hly-scpB-rib $14.0 \%$ $(6 / 43)$ profiles (Table 3$)$. The PCR assay for detection of 'VFs revealed that high percentage of the GBS isolates were positive for hly 97.8\% (42/43); scpB 90.1\% (39/ 43 ) and bca 86.0\% (37/43) (Table 5). The high prevalence of these genes in GBS has been previously reported [9, 36-38].

A Zimbabwean study reported a $46.3 \%$ of Rib (rib) protein marker as well as $19.8 \%$ and $15.7 \%$ of $\mathrm{C \alpha}(b c a)$ and $C \beta$ (bac) protein markers, respectively [11]. The low frequency obtained for the $\beta$ protein marker agrees with the $11.6 \%$ for bac observed in this study and this can be attributed to the reported low distribution of the $\mathrm{Ib}$ and II CPA types $(11.6 \%$ and $8.3 \%$, respectively) in the 
Zimbabwean GBS population [11]. However, contrary to their findings, the present study reports higher prevalence of rib (69.8\%) and bca (86.0\%). This discrepancy could be attributed to differences in CPA types for GBS isolates in these two studies among other factors. Comparisons with this 2008 study, highlighted the importance of investigating the CPA of GBS isolates because a relationship was observed between protein markers and CPA types [11].

Lower frequencies for genes $r i b$ and $b c a$, are reported by Manning et al., (2006) and Persson et al., (2008) with $28 \%$ and $43 \%$ for $r i b$ and $29 \%$ and $14 \%$ for $b c a$ in the USA [39] and Sweden [40] respectively. However, our higher frequencies agree with the $76.1 \%$ for $r i b$ and 88.6\% for $b c a$ reported in Argentina [41]. The bac gene in the present study was found at a similar frequency to the aforementioned studies in USA and Sweden: 11.6\% for bac, compared with $20 \%$ and $12 \%$ for bac, in the USA and Sweden respectively. The study in Argentina observed a higher frequency of 52.3\% for bac. A 2017 study in Egypt also observed high frequencies for $s c p B$ in $100 \%$ and $r i b$ in $79.2 \%$ and a lower frequency for $b a c$ (35.8\%) in GBS isolates. However, none of this study's isolates possessed the $b c a$ gene [29]. Our comparison with studies from these four countries USA, Sweden, Argentina and Egypt shows that any discrepancies are possibly a result of the geographical locations among other factors.

The results also showed that the majority of the isolates had more than three virulence genes. This high prevalence of various VFs in S. agalactiae isolates from the vaginal canal of pregnant women could lead to the development of serious maternal and neonatal infections [42]. However, this study was not able to follow up on the outcomes of both the pregnant mothers and their newborns. The high incidences of VFs except for $b a c$, also suggest that GBS vaccines containing the proteins ScpB, $\alpha$ protein [43], Rib [11] and hyaluronate lyase [44] could potentially be effective against our population of pregnant women in Zimbabwe.

The present study observed that all the isolates 100\% $(n=5)$ carrying the $b a c$ gene also carry the unrelated $b c a$ gene, whilst $86.5 \%(n=32)$ of the $b c a$ carrying isolates did not also have the $b a c$ gene (see Additional file 2: Table S2). This finding agrees with the report that, isolates that express $\beta$ tend to also express the unrelated $\alpha$ protein, while the $\alpha$ protein is often expressed on its own in GBS isolates $[45,46]$. The majority of the Spearman rank analysis were not statistically significant and with some showing weak associations. However, a significant negative correlation (see Additional file 2: Table S5) was detected between hly and IS1548 as well as between bac and rib genes $(P<0.01)$. This negative association is most likely because these genes are not genetically linked.

\section{Multi-drug resistance}

Multi-drug resistance was shown in $67.4 \%$ (29/43) of the isolates with 21 patterns identified (Table 3). Our MDR value is much higher than the $43.9 \%$ reported in Ethiopia [21] and yet lower than the 90\% reported in GBS in China [47]. Differences in MDR frequencies could be due to use of different antimicrobials, MDR definitions and AST methods. The high resistance observed using disk diffusion method was confirmed by our comparatively higher $\mathrm{MIC}_{50} \mathrm{~S}$ and $\mathrm{MIC}_{90} \mathrm{~S}$ (Table 2) for ampicillin, vancomycin and chloramphenicol to those reported in a GBS study in Japan [48]. The lowest resistance in our study was observed in $30.2 \%(13 / 43)$ of the GBS isolates to both vancomycin and erythromycin (Table 2). Lower resistance of $17 \%, 7.5 \%$ and $0 \%$ to vancomycin, erythromycin and chloramphenicol respectively has been reported by Assefa et al. [21] and other researchers [20,33]. Higher resistance to chloramphenicol (45\%) in GBS isolates has been reported in Iran [15]. Our results showed a 34.9\% (15/43) resistance to chloramphenicol using disk diffusion method and $0 \%(0 / 43)$ resistance using the E-test strips (MICs, $\geq 16 \mu \mathrm{g} / \mathrm{ml}$ ). This is because $93.5 \%(29 / 31)$ isolates which had tested intermediate or resistant to chloramphenicol by disk diffusion, were determined to be susceptible by E-test strips (see Additional file 2: Table S4). Both the disk diffusion and E-test results vancomycin showed similar results except for three isolates.

A high resistance to penicillin G $69.8 \%$ (30/43) and ampicillin 58.1\% (25/43) (disk diffusion method) and $46.5 \%(20 / 43)$ (E-test strips) was observed. This is because five isolates had resistance to ampicillin by disk diffusion but were determined to be susceptible by Etest strips (MICs, $\leq 0.25 \mu \mathrm{g} / \mathrm{ml}$ ). The high resistance is contrary to most studies which report a uniform susceptibility of $100 \%$ to all GBS isolates in pregnant women $[14,18,33,49,50]$. However, our results agree with recent findings in Ethiopia were a resistance of $77.3 \%$ to penicillin G was reported in pregnant women [19]. Other studies have reported resistance to both penicillin G and ampicillin of $10.2 \%$ and $9.2 \%$ as well as $19.5 \%$ and $14.6 \%$ respectively $[20,21]$. The high resistance reported may be due to the wide and non-prescription use of these two drugs in our study area $[49,51]$. It may also be as a result of differences in laboratory procedures or bacterial strains. This study also reports resistance to other penicillin surrogates [52] such as ceftriaxone $46.5 \%(20 / 43)$ and cefazolin $72.1 \%$ (31/43). A similar observation of approximately $31 \%$ for ceftriaxone was reported [20,53], whilst a lower range of $0 \%-15 \%$ for cefazolin has been reported [53-55]. We recommend that antibiotic susceptibility testing should be performed if penicillin $\mathrm{G}$ or ampicillin therapy is needed in the prevention of neonatal GBS infection. Further studies could 
focus on identifying the genes responsible for the observed resistance.

\section{Tetracyline resistance}

The high resistance for GBS to tetracycline $97.7 \%$ (42/ 43) (Table 2) can be attributed to a high presence of the tetM gene 97.6\% (41/42) (see Additional file 1: Fig. 9). This high tet $M$ gene presence is as a result of the ubiquitous presence of tet genes in pathogens, opportunistic pathogens and members of the normal flora [56]. The high resistance to tetracycline is also because the antibiotic is a relatively cheap, extensively used prophylaxis in the therapy of animal and human infections. It is known that bacterial strains tend to be resistant to frequently used antibiotics [51]. A low presence rate of the tetO 2.4\% (1/42) (Table 5) indicates that this gene is not common in GBS isolates that are resistant to tetracycline. These results agree with studies done in Canada [57] and Nigeria [58]. In Kuwait, they also reported similar results with $89.5 \%$ tetracycline-resistant isolates carrying $94.5 \%$ tet $M$ and $3.9 \%$ tet $O$ genes [59].

\section{Erythromycin and clindamycin resistance}

The current study results showed a $30.2 \%(13 / 43)$ and $55.8 \%(24 / 43)$ resistance to erythromycin and clindamycin respectively (Table 2). Such resistance decreases the options of prophylaxis in penicillin allergic women [60]. This combined with the high resistance of GBS to penicillin and ampicillin, we recommend that AST should be performed if clindamycin or erythromycin therapy is needed in the prevention of neonatal GBS infection. Future studies should focus on finding suitable alternative antibiotics for GBS chemoprophylaxis in pregnant women. PCR detected 34.5\% (10/29) ermB, 10.3\% (3/29) ermTR and $3.4 \%(1 / 29)$ mefA from the intermediate and resistant erythromycin GBS (Table 5). The prevalence of the $\operatorname{ermB}$ determinant shows that GBS commonly use target methylation as the mechanism of macrolide resistance.

Studies done in Italy [61], South Africa [14], USA [16], Iran [15] and France [25] reported similar findings, with most of the studies also observing that the ermB gene is more prevalent in distribution than the ermTR gene among GBS strains. This study also confirmed findings by Poyart et al., (2003) that the mefA gene is rare among GBS isolates, thus efflux pumps mediated by this gene are not a common mechanism of macrolide resistance [25]. Contrary to Bolukaoto et al., (2015) this current study did not find any $\operatorname{lin} B$ genes $0 \%(0 / 35)$ in any of the clindamycin resistant and intermediate strains [14]. In such cases, where multiple independent resistance genes can cause resistance, the observed phenotypic resistance can be attributed to any of the other known genes or genes that are yet to be discovered. This however limits the usefulness of such diagnostic tests.

It was interesting to note that $63.6 \%(7 / 11)$ GBS which were resistant to both erythromycin and clindamycin had the ermB gene (see Additional file 2: Table S2 and S3) and that one GBS strain which was resistant to erythromycin and susceptible to clindamycin carried the ermTR gene. Such observations are similar to other studies $[16,62,63]$.

\section{Genetic linkage in macrolide/tetracycline resistance determinant}

It was also observed that $100 \%(n=10)$ isolates that carried the $\operatorname{erm} B$ gene also carried the tet $M$ gene. The association of erythromycin and tetracycline resistance may be due to the conjugative transposon Tn1545, which encodes erythromycin resistance via the $\operatorname{erm} B$ gene and tetracycline resistance via the tet $M$ gene [64-66]. This association was supported by our analysis which showed a positive correlation (see Additional file 2: Table S5) between the two genes, but this lacked statistical significance according to the Spearman Rank test. Contrary to an Egyptian study [67], we report that there is no evidence suggesting genetic linkage of tet $O$ with $\operatorname{ermB}$, ermTR or mefA in our GBS population.

\section{Unexpressed resistant genotypes}

An unexpected observation in our study was found in the following three $(7.0 \%)$ isolates. Isolate 127 which was tetracycline sensitive, and yet the tet $M$ gene was detected. Isolates 243 and 322, were both erythromycin sensitive however, at least one gene ermTR or mefA was found, respectively (see Additional file 2: Table S2 and S3). Similar findings were reported in GBS and other streptococcal species [66, 68-70]. However, based on the disk diffusion test, this observation suggests that the Kirby Bauer disk diffusion method is inadequate for detection of resistance. Although the reason(s) behind this lack of gene expression still has to be determined, some possible explanations include gene mutations, absence of selection pressure (i.e. presence of antibiotic), low expression levels of the gene and the possibility of a weak, distant or absent promoter [66, 71, 72]. This study therefore supports the idea that the resistance genotype does not always accurately predict phenotypic resistance.

\section{Conclusion}

An increased resistance against penicillin G, ampicillin, tetracycline, erythromycin, vancomycin and clindamycin among other drugs was observed. The antibiotics erythromycin and vancomycin can be reliable alternatives in treating or preventing GBS infection in women who suffer from colonization or participants that are allergic to penicillin in Harare and Chitungwiza. However, 
prescribing antibiotic without antibacterial susceptibility tests should be avoided because of the high prevalence of resistance. The tetracycline resistance encoded by ribosome protection gene tet $M$ and the ribosomal methylation encoded by erythromycin ribosomal methylase gene, ermB were the two most common mechanisms of resistance in GBS from pregnant women. Current study results also showed that resistance genotypes do not always accurately predict phenotypic resistance.

A high frequency of the virulence genes: $h l y, s c p B, b c a$ and $r i b$ was detected in GBS and the majority of the isolates carried multiple virulence genes which showed that GBS's ability to adhere, colonize, destroy and invade tissues is important in the organism's pathogenesis. The bac gene and the Mobile Genetic Element (IS1548) were rarely found among the GBS isolates from pregnant women.

\section{Limitations of the study}

It would have been necessary to test each isolate using an in vivo animal model, such as mice to demonstrate actual virulence and investigate the expression of resistant genes. A small number of isolates was included from the two centres, which might have caused some bias. Our disc-diffusion assay had no replicates, and this is statistically a weak point. Also pipetting a fixed volume of inoculum for each assay plate is a better method of controlling the volume of inoculum used. In future studies it may be useful to collect information on comorbidities in participants whose analysis would be related to the various VFs identified.

\section{Supplementary Information}

The online version contains supplementary material available at https://doi. org/10.1186/s12879-021-05820-6.

Additional file 1. Gel Electrophoresis Pictograms (Fig. 1 to Fig. 9).

Additional file 2: Five supplementary tables; Table S1. The

oligonucleotide primers used for amplifying various genes in GBS. Table

S2. Presence or absence of the expected amplicons in the 43 GBS

isolates. Table S3. Presence or absence of antibiotic resistance genes in the resistant and intermediate isolates. Table S4. Disk diffusion zone diameters and E-test results for the 43 GBS isolates. Table S5. GBS Virulence and Antibiotic Resistance Genes Spearman Rank Correlations.

\section{Abbreviations}

GBS: Group B Streptococcus; VF: virulence factors; CDC: Centers for Disease Control; WHO: World Health Organization; CPA: capsular polysaccharide antigens; MGE: mobile genetic elements; MLSB: Macrolides, Lincosamides, and Streptogramin B; ANC: Antenatal Care; PCR: Polymerase Chain Reaction; AST: Antimicrobial susceptibility testing

\section{Acknowledgements}

The authors would like to express their gratitude to the members of the Department of Medical Microbiology and the Department of Chemical Pathology (University of Zimbabwe). We would like extend our great appreciation to Dr. L R. Mazengera and the staff of Immuno-Path Diagnostic Laboratory Services, the National Microbiology Reference Laboratory (NMRL) and the Department of Medicine (University of Zimbabwe) for their facilities and equipment. We extend our gratitude to Harare and Chitungwiza central hospitals ANC staff for helping during recruitment, and our heartfelt gratitude to ANC mothers who consented to participate in our study. We also ac knowledge Letten Foundation for financial support for sample collection. We wish to thank and acknowledge the support given by Taona Mudhluli.

\section{Authors' contributions}

RM, RTM, MGM: conceived the idea and contributed to the study design. MGM: Cohort recruitment, sample collection and completed the antibiotic resistance testing. RM: designed and performed the molecular testing. RTM: designed and supervised the project. RM, RTM: analyzed data and interpreted the results. RM, RTM, MGM: wrote manuscript. All authors read and approved the final paper for publication.

\section{Funding}

Letten Foundation funded the sample collection. The funders had no role in the design of the study and collection, analysis, and interpretation of data and in writing the manuscript.

\section{Availability of data and materials}

All data generated or analysed during this study are included in this published article [and its supplementary information files].

\section{Ethics approval and consent to participate}

This study obtained approvals from the institutions involved namely Harare Central Hospital (HCHEC 080416/21); Chitungwiza Central Hospital ethics committees (dated 28/04/16) which approved sample collection from their hospital antenatal clinics and the Joint Research Ethics Committee (JREC) 341/17) for the College of Health Sciences and Parirenyatwa Group of Hospitals. The study was also approved by Medical Research Council of Zimbabwe (MRCZ A/2054) and (MRCZ/B/1403). All information of participants was kept confidential. Written informed consent from the study participants was sought and granted by the participants. All information and data regarding of the participants was kept confidential and it was only accessible to personnel involved in the study. All electronic data was password protected.

\section{Consent for publication}

Not Applicable.

\section{Competing interests}

The authors declare that they have no competing interests.

\section{Author details}

${ }^{1}$ Department of Medical Microbiology, National Polio Laboratory, University of Zimbabwe College of Health Sciences, P. O. Box A178, Avondale, Harare, Zimbabwe. ${ }^{2}$ Faculty of Health Sciences, Institute of Infectious Diseases and Molecular Medicine, University of Cape Town, Room No. 3.22 Falmouth Building, Anzio Road, Observatory, Cape Town 7925, South Africa.

Received: 3 January 2020 Accepted: 19 January 2021

Published online: 28 January 2021

\section{References}

1. Verani JR, MCGee L, Schrag SJ. Prevention of Perinatal Group B Streptococcal Disease: Revised Guidelines from CDC, 2010 [Internet]. 2010 [cited 2018 Sep 25] p. 1-32. Report No.: 59(RR10). Available from: https:// www.cdc.gov/mmwr/preview/mmwrhtml/rr5910a1.htm

2. Larsen B, Monif GRG. Understanding the bacterial Flora of the female genital tract. Clin Infect Dis. 2001;32(4):e69-77.

3. Rosen GH, Randis TM, Desai PV, Sapra KJ, Ma B, Gajer P, et al. Group B streptococcus and the vaginal microbiota. J Infect Dis. 2017;216(6):744-51.

4. Rosenau A, Martins K, Amor S, Gannier F, Lanotte P, van der Mee-Marquet $\mathrm{N}$, et al. Evaluation of the ability of Streptococcus agalactiae strains isolated from genital and neonatal specimens to bind to human fibrinogen and correlation with characteristics of the fbsA and fbsB genes. Infect Immun. 2007:75(3):1310-7.

5. Mavenyengwa RT, Afset JE, Schei B, Berg S, Caspersen T, Bergseng $H$, et al Group B streptococcus colonization during pregnancy and maternal-fetal transmission in Zimbabwe. Acta Obstet Gynecol Scand. 2010;89(2):250-5. 
6. Smith TC, Roehl SA, Pillai P, Li S, Marrs CF, Foxman B. Distribution of novel and previously investigated virulence genes in colonizing and invasive isolates of Streptococcus agalactiae. Epidemiol Infect. 2007;135(6):1046-54.

7. Martínez $\mathrm{JL}$, Coque TM, Baquero F. What is a resistance gene? Ranking risk in resistomes. Nat Rev Microbiol. 2015;13(2):116-23.

8. Rajagopal L. Understanding the regulation of group B streptococcal virulence factors. Future Microbiol. 2009;4(2):201-21.

9. Emaneini M, Khoramian B, Jabalameli F, Abani S, Dabiri H, Beigverdi R. Comparison of virulence factors and capsular types of Streptococcus agalactiae isolated from human and bovine infections. Microb Pathog. 2016; 91:1-4.

10. Mitchell TJ. The pathogenesis of streptococcal infections: from tooth decay to meningitis : nature reviews microbiology. Nat Rev Microbiol. 2003;1:219-30.

11. Mavenyengwa RT, Maeland JA, Moyo SR. Distinctive features of surfaceanchored proteins of Streptococcus agalactiae strains from Zimbabwe revealed by PCR and dot blotting. Clin Vaccine Immunol CVI. 2008;15(9): $1420-4$

12. Moyo SR, Maeland JA, Bergh K. Typing of human isolates of Streptococcus agalactiae (group B streptococcus, GBS) strains from Zimbabwe. J Med Microbiol. 2002;51(7):595-600.

13. Dmitriev A, Suvorov A, Shen AD, Yang YH. Clinical diagnosis of group B streptococci by scpB gene based PCR. Indian J Med Res. 2004;119(Suppl): 233-6.

14. Bolukaoto JY, Monyama CM, Chukwu MO, Lekala SM, Nchabeleng M, Maloba MRB, et al. Antibiotic resistance of Streptococcus agalactiae isolated from pregnant women in Garankuwa, South Africa. BMC Res Notes. 2015;8 [cited 2017 Feb 27]. Available from: http://www.ncbi.nlm.nih.gov/pmc/ articles/PMC4544793/.

15. Emaneini M, Mirsalehian A, Beigvierdi R, Fooladi AAl, Asadi F, Jabalameli F, et al. High incidence of macrolide and tetracycline resistance among streptococcus Agalactiae strains isolated from clinical samples in Tehran, Iran. Mædica. 2014;9(2):157-61.

16. Heelan JS, Hasenbein ME, McAdam AJ. Resistance of group B streptococcus to selected antibiotics, including erythromycin and clindamycin. J Clin Microbiol. 2004;42(3):1263-4.

17. Mengist A, Kannan H, Abdissa A. Prevalence and antimicrobial susceptibility pattern of anorectal and vaginal group B streptococci isolates among pregnant women in Jimma, Ethiopia. BMC Res Notes. 2016;9(1):351.

18. Alemseged G, Niguse S, Hailekiros H, Abdulkadir M, Saravanan M, Asmelash T. Isolation and anti-microbial susceptibility pattern of group $B$ streptococcus among pregnant women attending antenatal clinics in Ayder referral hospital and Mekelle health center, Mekelle, northern Ethiopia. BMC Res Notes. 2015;8(1):518.

19. Mengist HM, Zewdie O, Belew A, Dabsu R. Prevalence and drug susceptibility pattern of group B streptococci (GBS) among pregnant women attending antenatal care (ANC) in Nekemte referral hospital (NRH), Nekemte, Ethiopia. BMC Res Notes. 2017;10(1):388.

20. Gizachew M, Tiruneh M, Moges F, Adefris M, Tigabu Z, Tessema B. Streptococcus agalactiae from Ethiopian pregnant women; prevalence, associated factors and antimicrobial resistance: alarming for prophylaxis. Ann Clin Microbiol Antimicrob. 2019;18(1):3.

21. Assefa S, Desta K, Lema T. Group B streptococci vaginal colonization and drug susceptibility pattern among pregnant women attending in selected public antenatal care centers in Addis Ababa, Ethiopia. BMC Pregnancy Childbirth. 2018;18(1):135.

22. Kimura K, Suzuki S, Wachino J, Kurokawa H, Yamane K, Shibata N, et al. First molecular characterization of group B streptococci with reduced penicillin susceptibility. Antimicrob Agents Chemother. 2008;52(8):2890-7.

23. Kasahara K, Baltus AJ, Lee S-H, Edelstein MA, Edelstein PH. Prevalence of non-penicillin-susceptible group B streptococcus in Philadelphia and specificity of penicillin resistance screening methods. J Clin Microbiol. 2010; 48(4):1468-9.

24. Sadowy E, Matynia B, Hryniewicz W. Population structure, virulence factors and resistance determinants of invasive, non-invasive and colonizing Streptococcus agalactiae in Poland. J Antimicrob Chemother. 2010;65(9): 1907-14.

25. Poyart C, Jardy L, Quesne G, Berche P, Trieu-Cuot P. Genetic basis of antibiotic resistance in Streptococcus agalactiae strains isolated in a French hospital. Antimicrob Agents Chemother. 2003;47(2):794-7.

26. Fluit AC, Visser MR, Schmitz F-J. Molecular detection of antimicrobial resistance. Clin Microbiol Rev. 2001;14(4):836-71.
27. Al Safadi R, Amor S, Hery-Arnaud G, Spellerberg B, Lanotte P, Mereghetti L, et al. Enhanced expression of Imb gene encoding laminin-binding protein in Streptococcus agalactiae strains harboring IS1548 in scpB-Imb intergenic region. PLoS One. 2010;5(5):e10794.

28. Keen EC. Paradigms of pathogenesis: targeting the mobile genetic elements of disease. Front Cell Infect Microbiol. 2012;2 [cited 2017 Feb 22]. Available from: http://www.ncbi.nlm.nih.gov/pmc/articles/PMC3522046/.

29. Sadaka Salama M, Aly Hala A, Meheissen Marwa A, Orief Yasser I, Arafaa Basma M. Group B streptococcal carriage, antimicrobial susceptibility, and virulence related genes among pregnant women in Alexandria, Egypt. Alex J Med. 2017; [cited 2017 May 31]; Available from: http://www.sciencedirect. com/science/article/pii/S209050681630197X

30. de Paris F, Machado ABMP, Gheno TC, Ascoli BM, de Oliveira KRP, Barth. Group B streptococcus detection: comparison of PCR assay and culture as a screening method for pregnant women. Braz I Infect Dis Off Publ Braz Soc Infect Dis. 2011;15(4):323-7.

31. Moyo SR, Mudzori J, Tswana SA, Maeland JA. Prevalence, capsular type distribution, anthropometric and obstetric factors of group B streptococcus (Streptococcus agalactiae) colonization in pregnancy. Cent Afr J Med. 2000; 46(5):115-20.

32. Clinical Laboratory Standard Institute. Performance standards for antimicrobial susceptibility testing. 27th ed CLSI supplement M100. Vol. 37. Wayne: Clinical and Laboratory Standards Institute; 2017. p. 84-8.

33. Khan MA, Faiz A, Ashshi AM. Maternal colonization of group B streptococcus: prevalence, associated factors and antimicrobial resistance. Ann Saudi Med. 2015;35(6):423-7.

34. Gavino M, Wang E. A comparison of a new rapid real-time polymerase chain reaction system to traditional culture in determining group $B$ streptococcus colonization. Am J Obstet Gynecol. 2007;197(4):388.e1-4.

35. Alfa MJ, Sepehri S, De Gagne P, Helawa M, Sandhu G, Harding GKM. Realtime PCR assay provides reliable assessment of Intrapartum carriage of group B streptococcus. J Clin Microbiol. 2010;48(9):3095-9.

36. Beigverdi R, Jabalameli F, Mirsalehian A, Hantoushzadeh S, Boroumandi S, Taherikalani M, et al. Virulence factors, antimicrobial susceptibility and molecular characterization of Streptococcus agalactiae isolated from pregnant women. Acta Microbiol Immunol Hung. 2014;61(4):425-34.

37. Eskandarian N, Ismail Z, Neela V, van Belkum A, Desa MNM, Amin NS. Antimicrobial susceptibility profiles, serotype distribution and virulence determinants among invasive, non-invasive and colonizing Streptococcus agalactiae (group B streptococcus) from Malaysian patients. Eur J Clin Microbiol Infect Dis Off Publ Eur Soc Clin Microbiol. 2015;34(3):579-84

38. Maeland JA, Brakstad OG, Bevanger L, Krokstad S. Distribution and expression of bca, the gene encoding the c alpha protein, by Streptococcus agalactiae. J Med Microbiol. 2000;49(2):193-8.

39. Manning SD, Ki M, Marrs CF, Kugeler KJ, Borchardt SM, Baker CJ, et al. The frequency of genes encoding three putative group B streptococcal virulence factors among invasive and colonizing isolates. BMC Infect Dis. 2006;6:116.

40. Persson E, Berg S, Bevanger L, Bergh K, Valsö-Lyng R, Trollfors B. Characterisation of invasive group $B$ streptococci based on investigation of surface proteins and genes encoding surface proteins. Clin Microbiol Infect. 2008;14(1):66-73.

41. Oviedo P, Pegels E, Laczeski M, Quiroga M, Vergara M. Phenotypic and genotypic characterization of Streptococcus agalactiae in pregnant women. First study in a province of Argentina. Braz I Microbiol Publ Braz Soc Microbiol. 2013;44(1):253-8.

42. Jedrzejas MJ, Chantalat L. Structural studies of streptococcus agalactiae hyaluronate lyase. Acta Crystallogr D Biol Crystallogr. 2000;56(Pt 4):460-3.

43. Xue G, Yu L, Li S, Shen X. Intranasal immunization with GBS surface protein sip and $\mathrm{ScpB}$ induces specific mucosal and systemic immune responses in mice. FEMS Immunol Med Microbiol. 2010;58(2):202-10.

44. Li S, Taylor KB, Kelly SJ, Jedrzejas MJ. Vitamin C inhibits the enzymatic activity ofStreptococcus pneumoniae hyaluronate Lyase. J Biol Chem. 2001; 276(18):15125-30.

45. Lachenauer CS, Creti R, Michel JL, Madoff LC. Mosaicism in the alpha-like protein genes of group B streptococci. Proc Natl Acad Sci U S A. 2000; 97(17):9630-5.

46. Dmitriev A, Hu YY, Shen AD, Suvorov A, Yang YH. Chromosomal analysis of group B streptococcal clinical strains; bac gene-positive strains are genetically homogenous. FEMS Microbiol Lett. 2002;208(1):93-8. 
47. Wang P, Ma Z, Tong J, Zhao R, Shi W, Yu S, et al. Serotype distribution, antimicrobial resistance, and molecular characterization of invasive group $B$ streptococcus isolates recovered from Chinese neonates. Int J Infect Dis. 2015:37:115-8

48. Matsubara K, Nishiyama Y, Katayama K, Yamamoto G, Sugiyama M, Murai T, et al. Change of antimicrobial susceptibility of group B streptococci over 15 years in Japan. J Antimicrob Chemother. 2001;48(4):579-82.

49. Teatero S, Ferrieri P, Martin I, Demczuk W, McGeer A, Fittipaldi N. Serotype distribution, population structure, and antimicrobial resistance of group $B$ streptococcus strains recovered from colonized pregnant women. J Clin Microbiol. 2017;55(2):412-22.

50. Tor-Udom S, Tor-Udom P, Hiriote W. The prevalence of streptococcus agalactiae (group B) colonization in pregnant women at Thammasat hospital. J Med Assoc Thail Chotmaihet Thangphaet. 2006;89(4):411-4.

51. Mbanga J, Mudzana R. Virulence factors and antibiotic resistance patterns of uropathogenic Escherichia coli. Afr J Microbiol Res. 2014;8(43):3678-86.

52. CLSI, editor. Performance standards for antimicrobial susceptibility testing. 27th ed. CLSI supplement M100. Wayne: Clinical and Laboratory Standards Institute; 2017.

53. Simoes JA, Aroutcheva AA, Heimler I, Faro S. Antibiotic resistance patterns of group B streptococcal clinical isolates. Infect Dis Obstet Gynecol. 2004; 12(1):1-8.

54. Manning SD, Pearlman MD, Tallman P, Pierson CL, Foxman B. Frequency of antibiotic resistance among group $B$ streptococcus isolated from healthy college students. Clin Infect Dis. 2001;33(12):e137-9.

55. Chohan L, Hollier LM, Bishop K, Kilpatrick CC. Patterns of antibiotic resistance among group B streptococcus isolates: 2001-2004. Infect Dis Obstet Gynecol. 2006;2006 [cited 2020 May 7]. Available from: https://www. ncbi.n/m.nih.gov/pmc/articles/PMC1581469/.

56. Chopra I, Roberts M. Tetracycline antibiotics: mode of action, applications, molecular biology, and epidemiology of bacterial resistance. Microbiol Mol Biol Rev. 2001;65(2):232-60.

57. Teatero S, McGeer A, Li A, Gomes J, Seah C, Demczuk W, et al. Population structure and antimicrobial resistance of invasive serotype IV group B streptococcus, Toronto, Ontario, Canada. Emerg Infect Dis. 2015;21(4):585-91.

58. Elikwu CJ, Oduyebo OO, Anorlu RI, Konig B. Antibiotic susceptibility/resistant gene profiles of group B streptococci isolates from pregnant women in a tertiary institution in Nigeria. J Clin Sci. 2016;13(3):132-6.

59. Boswihi SS, Udo EE, Al-Sweih N. Serotypes and antibiotic resistance in group B streptococcus isolated from patients at the maternity hospital, Kuwait. J Med Microbiol. 2012;61(Pt 1):126-31.

60. Capanna F, Emonet SP, Cherkaoui A, Irion O, Schrenzel J, Martinez de Tejada B. Antibiotic resistance patterns among group $B$ streptococcus isolates: implications for antibiotic prophylaxis for early-onset neonatal sepsis. Swiss Med Wkly. 2013;143:w13778

61. Matani C, Trezzi M, Matteini A, Catalani C, Messeri D, Catalani C. Streptococcus agalactiae: prevalence of antimicrobial resistance in vaginal and rectal swabs in Italian pregnant women. Infez Med Riv Period Eziologia Epidemiol Diagn Clin E Ter Delle Patol Infett. 2016;24(3):217-21.

62. Dela Cruz WP, Richardson JY, Broestler JM, Thornton JA, Danaher PJ. Rapid determination of macrolide and Lincosamide resistance in group $B$ streptococcus isolated from vaginal-rectal swabs. Infect Dis Obstet Gynecol. 2007;2007 [cited 2018 Aug 23]. Available from: https://www.ncbi.nlm.nih. gov/pmc/articles/PMC1939917/.

63. Gygax SE, Schuyler JA, Kimmel LE, Trama JP, Mordechai E, Adelson ME. Erythromycin and clindamycin resistance in group B streptococcal clinical isolates. Antimicrob Agents Chemother. 2006;50(5):1875-7.

64. Kresken M, Henrichfreise B, Bagel S, Brauers J, Wiedemann B. High prevalence of the ermB gene among erythromycin-resistant Streptococcus pneumoniae isolates in Germany during the winter of 2000-2001 and in vitro activity of Telithromycin. Antimicrob Agents Chemother. 2004;48(8): 3193-5.

65. Roberts MC, Sutcliffe J, Courvalin P, Jensen LB, Rood J, Seppala H. Nomenclature for macrolide and macrolide-lincosamide-streptogramin $B$ resistance determinants. Antimicrob Agents Chemother. 1999;43(12):2823-30.

66. Pinto TCA, Costa NS, de Corrêa ABA, de Oliveira ICM, de Mattos MC, Rosado AS, et al. Conjugative transfer of resistance determinants among human and bovine Streptococcus agalactiae. Braz J Microbiol. 2014;45(3):785-9.

67. Shabayek S, Abdalla S. Macrolide- and tetracycline-resistance determinants of colonizing group B streptococcus in women in Egypt. J Med Microbiol. 2014;63(Pt 10):1324-7.
68. Gao J, Yu F-Q, Luo L-P, He J-Z, Hou R-G, Zhang H-Q, et al. Antibiotic resistance of Streptococcus agalactiae from cows with mastitis. Vet J Lond Engl 1997. 2012;194(3):423-4.

69. Brenciani A, Bacciaglia A, Vecchi M, Vitali LA, Varaldo PE, Giovanetti E. Genetic elements carrying erm(B) in streptococcus pyogenes and association with tet( $M)$ tetracycline resistance gene. Antimicrob Agents Chemother. 2007;51(4):1209-16.

70. Cochetti I, Tili E, Vecchi M, Manzin A, Mingoia M, Varaldo PE, et al. New Tn916-related elements causing erm(B)-mediated erythromycin resistance in tetracycline-susceptible pneumococci. J Antimicrob Chemother. 2007;60(1): 127-31.

71. Zhang L, Levy K, Trueba G, Cevallos W, Trostle J, Foxman B, et al. Effects of selection pressure and genetic association on the relationship between antibiotic resistance and virulence in Escherichia coli. Antimicrob Agents Chemother. 2015:59(11):6733-40.

72. Lindahl G, Stålhammar-Carlemalm M, Areschoug T. Surface proteins of Streptococcus agalactiae and related proteins in other bacterial pathogens. Clin Microbiol Rev. 2005;18(1):102-27.

\section{Publisher's Note}

Springer Nature remains neutral with regard to jurisdictional claims in published maps and institutional affiliations.
Ready to submit your research? Choose BMC and benefit from:

- fast, convenient online submission

- thorough peer review by experienced researchers in your field

- rapid publication on acceptance

- support for research data, including large and complex data types

- gold Open Access which fosters wider collaboration and increased citations

- maximum visibility for your research: over $100 \mathrm{M}$ website views per year

At $\mathrm{BMC}$, research is always in progress.

Learn more biomedcentral.com/submissions 